\title{
Changes in biomass, lipid, fatty acid and elemental composition during the abbreviated larval development of the subantarctic shrimp Campylonotus vagans
}

\author{
Sven Thatje ${ }^{\mathrm{a}, *}$, Gustavo A. Lovrich ${ }^{\mathrm{b}}$, Gabriela Torres ${ }^{\mathrm{c}}$, \\ Wilhelm Hagen ${ }^{\mathrm{d}}$, Klaus Anger ${ }^{\mathrm{c}}$ \\ a Alfred Wegener Institute for Polar and Marine Research, P.O. Box 120 161, D-27515 Bremerhaven, Germany \\ ${ }^{\mathrm{b}}$ Consejo Nacional de Investigaciones Cientificas y Técnicas, Centro Austral de Investigaciones Cientificas, \\ CADIC, CC 92, V9410BFD Ushuaia, Tierra del Fuego, Argentina \\ ${ }^{\mathrm{c}}$ Biologische Anstalt Helgoland, Stiftung Alfred Wegener Institute for Polar and Marine Research, \\ Helgoland, Germany \\ ${ }^{\mathrm{d}}$ Marine Zoology (FB2), University of Bremen (NW2A), P.O. Box 330440, D-28334 Bremen, Germany
}

Received 1 May 2003; received in revised form 9 September 2003; accepted 30 September 2003

\begin{abstract}
Ontogenetic changes in biomass and chemical composition were studied in the laboratory during the abbreviated larval and early juvenile development of the caridean shrimp Campylonotus vagans from the subantarctic Beagle Channel, Argentina. At $7 \pm 0.5{ }^{\circ} \mathrm{C}$, development from hatching to metamorphosis took about 44 days. The larvae started feeding on Artemia nauplii immediately after hatching, although larval resistance to starvation was high (average 18 days, maximum 29 days). Dry mass (DM), carbon (C), nitrogen $(\mathrm{N})$ and hydrogen (H) contents increased about a fourfold from hatching to metamorphosis, while the $\mathrm{C}: \mathrm{N}$ mass ratio increased from about 3.7 to 4.3 . The protein and total lipid contents increased gradually from hatching to the first juvenile stage, the former from 190 to $640 \mu \mathrm{g} /$ individual, the latter from 37 to $95 \mu \mathrm{g} /$ individual. The lipid mass fraction was low throughout larval development (3-9\% of DM), while the protein content was much higher and almost constant $(30-40 \%)$. The dominating fatty acids were 18:1(n-9), 16:0, 20:5(n-3), 18:1(n-7), 18:3(n-3), 18:0, 16:1(n7). Except for 20:5(n-3), these resulted mainly from food uptake (Artemia nauplii). Exuvial losses of $\mathrm{C}, \mathrm{H}$ and $\mathrm{N}$ (all larval stages combined) accounted for only $7 \%, 1 \%$ and $1 \%$ of the initial values at hatching. In contrast, $37 \%$ of initial DM was lost. Partially food-independent
\end{abstract}

* Corresponding author. Tel.: +49-471-4831-1315; fax: +49-471-4831-1149.

E-mail address: sthatje@awi-bremerhaven.de (S. Thatje). 
(endotrophic) larval development is discussed as an adaptation to food scarcity at high latitudes, while the abbreviated planktotrophic larval development appears to be synchronised with seasonal peaks in primary production, allowing for an optimal resource exploitation in a food-limited environment.

(C) 2003 Elsevier B.V. All rights reserved.

Keywords: Abbreviated larval development; Fatty acids; Lipids; Protein; Shrimp; Southern Ocean

\section{Introduction}

On a macroecological scale, many marine invertebrate groups show a remarkable reduction in species diversity towards higher latitudes, probably best documented for marine bivalve molluscs (Crame, 1999, 2000a,b) and decapod crustaceans (Gorny, 1999). Both groups present a bell-shaped pattern with decreasing species diversity towards high latitudes. Among the decapods, only eight natant shrimp species have been found in the high Antarctic Weddell Sea (Arntz et al., 1992). Reptant crabs seem to be entirely absent from the high Antarctic shelf, although a few lithodid crab species have been found off the shelf, mostly at depths below 250 m (Klages et al., 1995; Arana and Retamal, 1999). In contrast, a high diversity of reptants has been recorded in cold-temperate areas of the subpolar regime (Gorny, 1999).

Strongly pronounced seasonality in planktonic food availability due to short periods of primary production is, besides low temperatures, presumably a major selective force in high latitudes (for discussion, see Clarke, 1987; Pearse et al., 1991; Knox, 1994). Species without a fully planktotrophic mode of larval development may thus have to adapt to such a food-limited conditions, synchronising their larval phase with short and pulsed primary production. However, the adaptability may be limited by physiological constraints associated with low temperatures, which cause slow development in both embryos and larvae (Clarke, 1982, 1983).

In the present study we have chosen the subantarctic caridean shrimp Campylonotus vagans Bate, 1888, as an example of early life history adaptations to strongly pulsed food availability. The family Campylonotidae shows several ecological and biogeographic patterns, which enable us to discuss our findings in a wider ecological context, and in relation to high Antarctic shrimp species. The Campylonotidae show a circumpolar distribution and consist of five representatives exclusively known from the Southern Ocean, one of which was recently discovered in Antarctic waters (Torti and Boschi, 1973; Thatje, 2003).

\section{Materials and methods}

\subsection{Capture and maintenance of ovigerous females}

Ovigerous $C$. vagans were caught in the Beagle Channel in September 2001 $\left(54^{\circ} 53^{\prime} \mathrm{S}, 68^{\circ} 17^{\prime} \mathrm{W}\right.$, Fig. 1) using an inflatable dinghy equipped with an epibenthic 


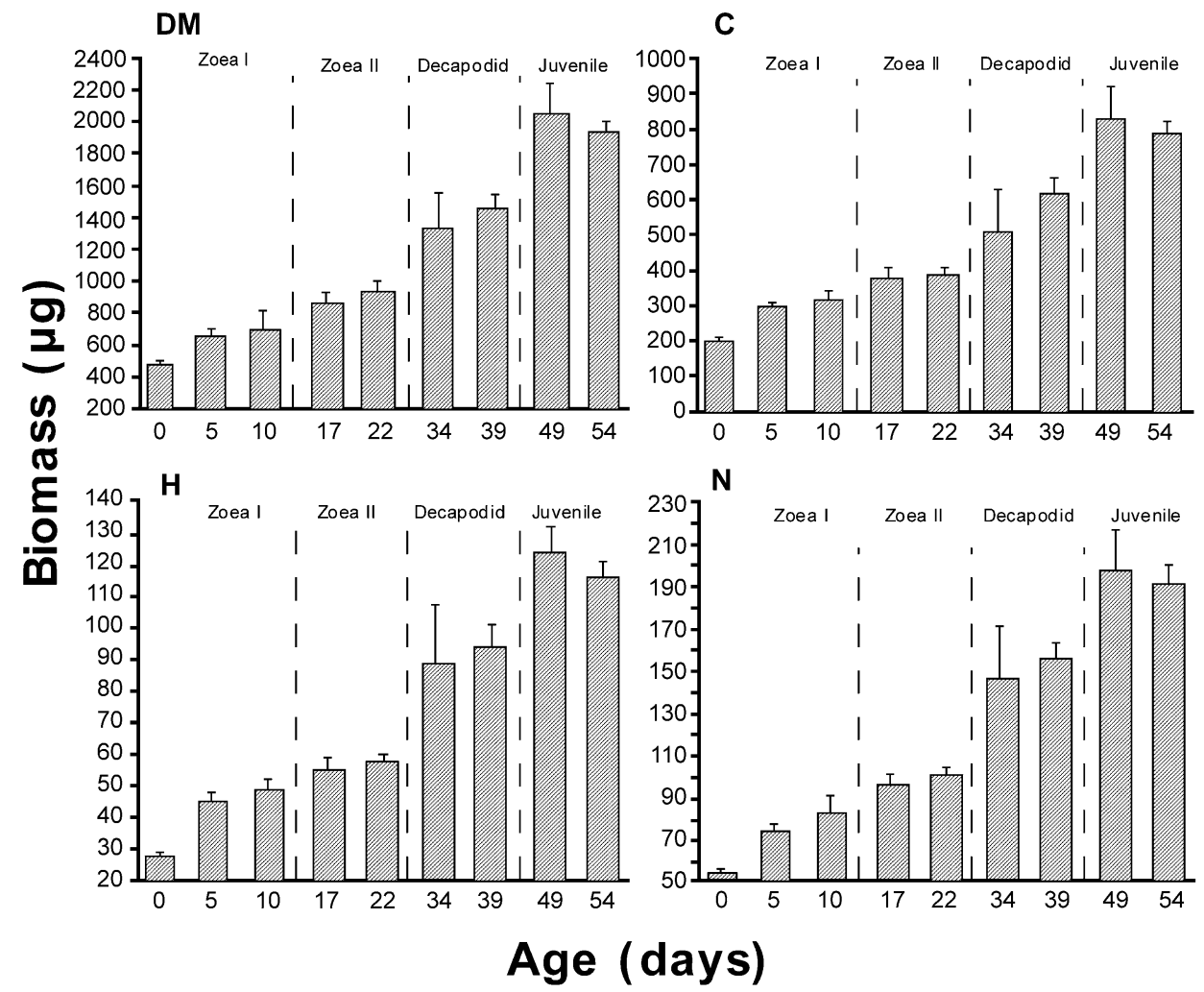

Fig. 1. C. vagans. Changes in dry mass (DM) and contents of carbon (C), nitrogen (N) and hydrogen (H) (all in $\mu \mathrm{g} /$ individual; $x \pm$ S.D.) during larval and early juvenile development in the presence of food (Artemia sp.).

trawl (1.7 m mouth width, net with $1 \mathrm{~cm}$ mesh size) at about $15 \mathrm{~m}$ depth. Maintenance of females and rearing of larvae took place in the local institute Centro Austral de Investigaciones Científicas (CADIC) in Ushuaia, Tierra del Fuego (Argentina), under constant conditions of temperature $\left(7.0 \pm 0.5^{\circ} \mathrm{C}\right.$ ), salinity (ca. 30), and a 12:12-h light/ dark rhythm.

Each female was kept individually in a tank of about 301 water content, equipped with permanent seawater flow from a closed circulation filter system. Food (commercial TETRA AniMin pellets for aquaristics, TetraWerke, Germany) was given twice a week.

\subsection{Rearing of larvae and juveniles}

The first larvae hatched at night, about a fortnight after capturing the ovigerous females. Due to strong demersal behaviour, the larvae were collected every night from the bottom of the aquaria using long glass pipettes. Each day, randomly selected larvae were transferred to individual rearing cups with about $100 \mathrm{ml}$ seawater, which were checked 
daily for dead or moulted individuals. Every other day, water was changed and food (Artemia sp. nauplii; Argent Chemical Laboratories, USA) was supplied.

The larval development of $C$. vagans passed invariably through two zoeal stages and one decapodid stage, with mean durations of 12, 17 and 15 days, respectively (see Thatje et al., 2004). Their separation was based on the appearance of an exuvia and visual observation of morphological differences (cf. Thatje et al., 2001; Thatje and Lovrich, 2003).

\subsection{Determination of dry mass $(D M)$ and elemental composition $(C, H, N)$}

Samples for the determination of dry mass (DM) and elemental composition $(\mathrm{C}, \mathrm{N}, \mathrm{H}$; with $n=5$ replicates each; one individual per replicate) were taken immediately after hatching (day 0) and subsequently on days 5 and 10 of each larval and the first juvenile instar (see Table 1). Larval samples for the study of physiological changes during the complete larval and early juvenile development resulted from the same females A and B in parallel rearings. Due to extremely low fecundity (Thatje et al., 2004), parallel analyses of unfed larvae are based on larval material from an additional female. Exuviae were sampled from each larval stage to quantify biomass losses during successive moults. Since a minimum of $0.2 \mu \mathrm{g}$ dry mass is needed for each elemental analysis, 10-20 exuviae (depending on availability) originating from two different females (females A + B) per replicate sample (with $n=1-6$ replicates) were pooled.

Dry mass was measured to the nearest $0.1 \mu \mathrm{g}$ on an autobalance (Mettler, UMT 2). $\mathrm{C}, \mathrm{N}$ and $\mathrm{H}$ contents of larvae and the first juvenile instar were analysed as described by Anger and Harms (1990): short rinsing in distilled water, blotting on fluff-free Kleenex paper for optical use, freezing at $-18{ }^{\circ} \mathrm{C}$, vacuum drying at $<10^{-2}$ mbar,

Table 1

C. vagans. Changes in dry mass (DM) and contents of carbon $(\mathrm{C})$, nitrogen $(\mathrm{N})$ and hydrogen $(\mathrm{H})($ all in percent of DM; $x \pm$ S.D.) during larval development and in the first juvenile shrimp stage in presence of food (Artemia sp.); age given in days (a) within each stage and (b) from hatching

\begin{tabular}{|c|c|c|c|c|c|c|c|c|c|c|c|}
\hline \multirow[t]{2}{*}{ Stage } & \multirow[t]{2}{*}{ Female } & \multicolumn{2}{|c|}{ Age } & \multicolumn{2}{|c|}{$\begin{array}{l}\mathrm{DM} \text { ( } \mu \mathrm{g} / \text { individual) } \\
\text { with Artemia }\end{array}$} & \multicolumn{2}{|c|}{$\begin{array}{l}\mathrm{C}(\% \mathrm{DM}) \\
\text { with Artemia }\end{array}$} & \multicolumn{2}{|c|}{$\begin{array}{l}\mathrm{N}(\% \mathrm{DM}) \\
\text { with Artemia }\end{array}$} & \multicolumn{2}{|c|}{$\begin{array}{l}\mathrm{H}(\% \mathrm{DM}) \\
\text { with Artemia }\end{array}$} \\
\hline & & (a) & (b) & $x$ & \pm & $x$ & \pm & $x$ & \pm & $X$ & \pm \\
\hline \multirow[t]{7}{*}{ Zoea I } & A & 0 & 0 & 493 & 8 & 40.8 & 0.8 & 11.1 & 0.2 & 5.8 & 0.1 \\
\hline & B & 0 & 0 & 426 & 55 & 43.5 & 5.0 & 11.8 & 1.5 & 6.2 & 0.7 \\
\hline & $\mathrm{C}$ & 0 & 0 & 474 & 15 & 41.5 & 1.0 & 10.9 & 0.2 & 5.9 & 0.1 \\
\hline & $\mathrm{D}$ & 0 & 0 & 416 & 36 & 42.4 & 0.6 & 11.7 & 0.3 & 6.2 & 0.1 \\
\hline & $\mathrm{E}$ & 0 & 0 & 406 & 29 & 41.9 & 0.9 & 11.1 & 0.5 & 5.9 & 0.1 \\
\hline & A & 5 & 5 & 668 & 25 & 44.0 & 0.5 & 11.2 & 0.2 & 6.7 & 0.1 \\
\hline & A & 10 & 10 & 712 & 77 & 44.0 & 0.5 & 11.6 & 0.3 & 6.7 & 0.1 \\
\hline \multirow[t]{2}{*}{ Zoea II } & A & 5 & 17 & 903 & 51 & 40.7 & 1.7 & 10.7 & 0.4 & 6.0 & 0.3 \\
\hline & A & 10 & 22 & 941 & 43 & 41.4 & 2.4 & 10.9 & 0.5 & 6.1 & 0.3 \\
\hline \multirow[t]{2}{*}{ Decapodid } & A & 5 & 34 & 1342 & 221 & 44.2 & 1.5 & 10.9 & 0.1 & 6.5 & 0.3 \\
\hline & A & 10 & 39 & 1446 & 49 & 44.3 & 1.6 & 10.8 & 0.3 & 6.6 & 0.3 \\
\hline \multirow[t]{2}{*}{ Juvenile } & A & 5 & 49 & 2077 & 122 & 40.8 & 0.9 & 9.6 & 0.3 & 6.0 & 0.2 \\
\hline & A & 10 & 54 & 1937 & 61 & 41.2 & 2.2 & 9.8 & 0.5 & 6.1 & 0.3 \\
\hline
\end{tabular}


weighing and combusting at $1020{ }^{\circ} \mathrm{C}$ in a Fison (Carlo Erba) 1108 Elemental Analyser.

\subsection{Protein analyses}

Samples for protein analyses $(n=5)$ were gently rinsed in distilled water, dried on filter paper, transferred individually into an Eppendorf vial and deep frozen at $-80{ }^{\circ} \mathrm{C}$. Protein samples were dried for $48 \mathrm{~h}$ using the Finn-Aqua Lyovac GT2E vacuum drier, and W was afterwards measured in a Sartorius MC1 RC $210 \mathrm{~S}$ Balance (precision: 0,01 mg, capacity 210 g). Following drying, samples were homogenised by sonication (Branson, Sonifer, Cell Disruptor B 15) and each homogenate was divided in two aliquots for protein analyses. We used the Lowry method for protein determination (Lowry et al., 1951), modified to perform measurements using microplates (Pfaff, 1997, Paschke, 1998). Spectrometric measurements were made in triplicate in a microplate spectrophotometer (750-nm filter, Dynatech, MR 7000).

\subsection{Total lipid and fatty acid analyses}

Since the amount of larval material in all biochemical studies was extremely limited due to low female fecundity, we calculated individual total lipid content on the basis of lipid extraction, precipitation and drying, previous to transesterification of the sample material for fatty acid analyses.

The fatty acid composition was determined by gas chromatography (Kattner and Fricke, 1986). Briefly, fatty acids were converted to methyl esters by transesterification in methanol containing $3 \%$ concentrated sulphuric acid at $80{ }^{\circ} \mathrm{C}$ for $4 \mathrm{~h}$. The obtained fatty acid methyl esters were then analysed using a gas chromatograph (GC) (HP6890) on a 30 $\mathrm{m} \times 0.25 \mathrm{~mm}$ i.d. wall-coated open tubular column (film thickness: $0.25 \mu \mathrm{m}$; liquid phase: DB-FFAP) using temperature programming. Fatty acids were identified with standard mixtures and quantified by internal standard (Kattner et al., 1998).

\subsection{Statistical analyses}

Differences in larval elemental composition at hatching were compared in five different females. Statistical differences were tested by means of a one-way ANOVA

Table 2

C. vagans. Changes in dry mass $(\mathrm{DM})$ and contents of carbon $(\mathrm{C})$, nitrogen $(\mathrm{N})$ and hydrogen $(\mathrm{H})($ all in percent of DM; $x \pm$ S.D.) in the zoea I stage in the absence of food; age given in days

\begin{tabular}{|c|c|c|c|c|c|c|c|c|c|c|}
\hline \multirow[t]{2}{*}{ Stage } & \multirow[t]{2}{*}{ Female } & \multirow[t]{2}{*}{ Age } & \multicolumn{2}{|c|}{$\begin{array}{l}\mathrm{DM}(\mu \mathrm{g} / \text { individual }) \\
\text { without Artemia }\end{array}$} & \multicolumn{2}{|c|}{$\begin{array}{l}\mathrm{C}(\% \mathrm{DM}) \\
\text { without Artemia } \\
\end{array}$} & \multicolumn{2}{|c|}{$\begin{array}{l}\mathrm{N}(\% \mathrm{DM}) \\
\text { without Artemia } \\
\end{array}$} & \multicolumn{2}{|c|}{$\begin{array}{l}\mathrm{H}(\% \mathrm{DM}) \\
\text { without Artemia }\end{array}$} \\
\hline & & & $x$ & \pm & $x$ & \pm & $x$ & \pm & $x$ & \pm \\
\hline \multirow[t]{3}{*}{ Zoea I } & $\mathrm{C}$ & 0 & 474 & 15 & 41.5 & 1.0 & 10.9 & 0.2 & 5.9 & 0.1 \\
\hline & $\mathrm{C}$ & 5 & 455 & 23 & 37.7 & 1.0 & 10.6 & 0.3 & 5.5 & 0.1 \\
\hline & $\mathrm{C}$ & 10 & 441 & 16 & 37.5 & 1.1 & 10.4 & 0.3 & 5.3 & 0.2 \\
\hline
\end{tabular}


(Sokal and Rohlf, 1995). Changes in dry mass, elemental composition (C, N, H), protein and lipid were described and compared with linear regressions in relation to larval age (Sokal and Rohlf, 1995). The elemental and protein data were log-transformed to achieve normality and homoscedasticity (tested with Kolmogorov-Smirnov and Bartlett's tests, respectively). Slopes of linear regressions were compared with an ANCOVA using the $F$-statistic (Sokal and Rohlf, 1995).

\section{Results}

\subsection{Changes in dry mass, $C, N, H$ and $C: N$ mass ratio}

The elemental composition and protein content of recently hatched larvae varied significantly among the five different females (DM, $F=6.753, \mathrm{C}, F=10.787, \mathrm{H}$, $F=13.218, \mathrm{~N}, F=10.707$, proteins $F=16.2$; all $P<0.001$ ).

First feeding was microscopically observed following hatching. Dry mass as well as $\mathrm{C}$, $\mathrm{H}$ and $\mathrm{N}$ increased significantly in fed larvae from hatching to metamorphosis, reaching fourfold higher values on day 5 of the first juvenile stage (Tables 1 and 3; Fig. 1). A stronger increase in the $\mathrm{C}$ fraction in relation to $\mathrm{DM}$ is reflected by an increasing $\mathrm{C}: \mathrm{N}$ mass ratio during larval development. This ratio remained comparably constant from day 5 to day 22 (end of zoea II stage), but increased subsequently from about 3.8 to 4.1 , when the decapodid stage was reached (Fig. 2).

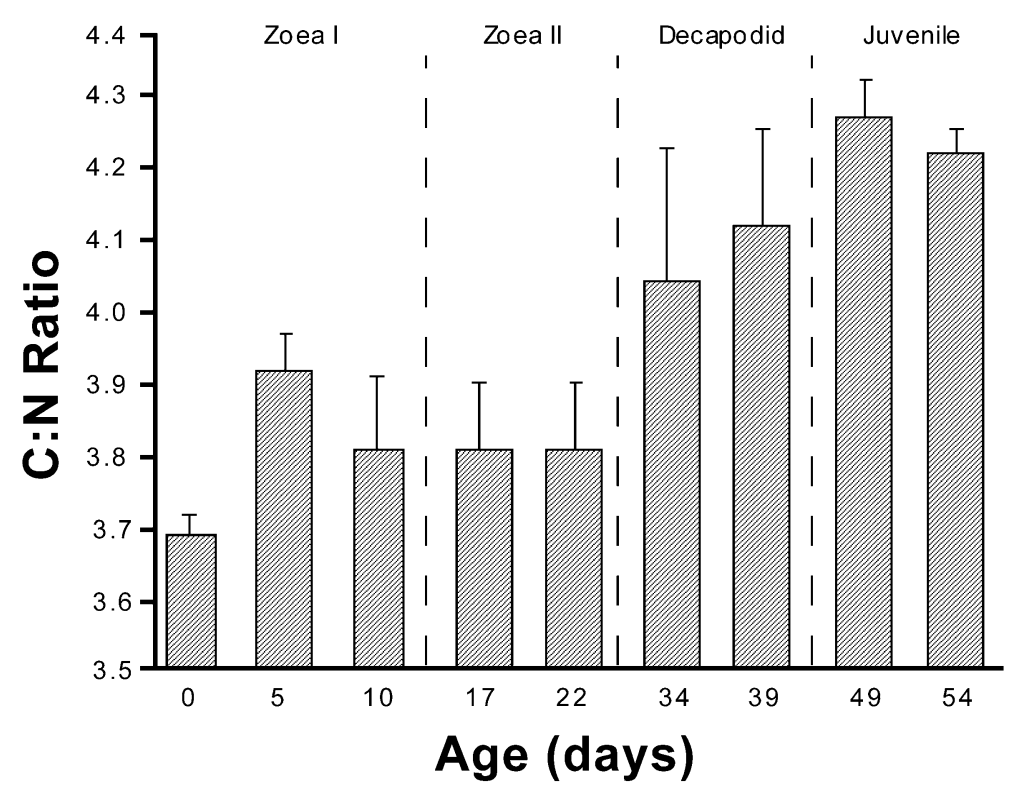

Fig. 2. C. vagans. Carbon/nitrogen $(\mathrm{C}: \mathrm{N})$ mass ratio during larval and early juvenile development in the presence of food (Artemia sp.). 
Table 3

C. vagans. Parameters of linear regressions describing changes in dry mass (DM), contents of carbon (C), nitrogen $(\mathrm{N})$, hydrogen $(\mathrm{H})$ (all in $\mu \mathrm{g}$ /individual, after logarithmic transformation) as functions of the time of development during larval development until day 5 of the first juvenile instar (i.e. day 49 of development)

\begin{tabular}{|c|c|c|c|c|c|}
\hline Stage & $\begin{array}{l}\text { Biomass } \\
\text { parameter }\end{array}$ & Slope & Intercept & $F$ reg & $P$ \\
\hline \multicolumn{6}{|l|}{ With Artemia } \\
\hline \multirow{5}{*}{$\begin{array}{l}\text { Zoea I-Decapodid } \\
\quad \text { (days } 0-49)\end{array}$} & $\mathrm{DM}$ & 0.012 & 2.735 & 925.0 & $<0.001$ \\
\hline & $\mathrm{C}$ & 0.012 & 2.362 & 627.5 & $<0.001$ \\
\hline & $\mathrm{H}$ & 0.012 & 1.533 & 466.2 & $<0.001$ \\
\hline & $\mathrm{N}$ & 0.011 & 1.790 & 774.5 & $<0.001$ \\
\hline & Proteins & 0.010 & 2.367 & 148.7 & $<0.001$ \\
\hline \multicolumn{6}{|l|}{ Without Artemia } \\
\hline \multirow[t]{5}{*}{ Zoea I (days 0-10) } & $\mathrm{DM}$ & -0.003 & 2.676 & 9.76 & 0.008 \\
\hline & $\mathrm{C}$ & -0.008 & 2.290 & 52.45 & $<0.001$ \\
\hline & $\mathrm{H}$ & -0.008 & 1.448 & 41.09 & $<0.001$ \\
\hline & $\mathrm{N}$ & -0.005 & 1.714 & 28.98 & $<0.001$ \\
\hline & Proteins & -0.008 & 2.365 & 1.951 & 0.186 \\
\hline
\end{tabular}

All slopes are significantly different from zero $(P<0.001)$; the slopes of regressions obtained from different treatments do not differ significantly from each other (ANCOVA: all $P>0.05$ ).

Despite the significant differences in elemental composition and protein content of recently hatched larvae among all five females, the initial elemental composition and protein contents of larvae from female A (with Artemia) and female C (without Artemia) were similar (Tukey post hoc tests for $\mathrm{C}, \mathrm{N}, \mathrm{H}$ and protein per larvae, all $P>0.41$; Tables 1-3). Larvae kept under starvation conditions (female $\mathrm{C}$ ) did not reach the moult to the zoea II stage. DM, C, N and $\mathrm{H}$ decreased significantly within the first 10 days of the zoea I (Table 3), when this sampling was finished due to lack of larval material. The protein content, in contrast, remained constant throughout this time span (cf. Table 2). Starved larvae survived on average about 14 days. In fed larvae, the proportion of $\mathrm{C}, \mathrm{N}$ and $\mathrm{H}$ (in \%DM) remained equal during the entire larval and early juvenile development (Table 1). C contributed always about $40-44 \%$

Table 4

C. vagans. Dry mass (DM), contents of carbon $(\mathrm{C})$, nitrogen $(\mathrm{N})$ and hydrogen $(\mathrm{H})(\mathrm{all}$ in $\mu \mathrm{g} /$ individual and in percent of $\mathrm{W}), \mathrm{C}: \mathrm{N}$ mass ratio of the exuviae of all larval stages; $x \pm \mathrm{S} . \mathrm{D}$.

\begin{tabular}{|c|c|c|c|c|c|c|c|c|c|c|c|c|}
\hline \multirow[t]{2}{*}{ Stage } & & \multirow[t]{2}{*}{$\mathrm{N}$} & \multicolumn{2}{|l|}{ DM } & \multicolumn{2}{|l|}{$\mathrm{C}$} & \multicolumn{2}{|l|}{$\mathrm{N}$} & \multicolumn{2}{|l|}{$\mathrm{H}$} & \multicolumn{2}{|c|}{$\mathrm{C}: \mathrm{N}$ mass ratio } \\
\hline & & & $x$ & \pm & $x$ & \pm & $x$ & \pm & $x$ & \pm & $x$ & \pm \\
\hline \multirow[t]{2}{*}{ Zoea I } & $\mu \mathrm{g} /$ ind. & 7 & 39.3 & 4.2 & 7.4 & 1.3 & 1.3 & 0.1 & 1.2 & 0.2 & 5.6 & 1.1 \\
\hline & $\% \mathrm{DM}$ & & 8.5 & 0.9 & 1.6 & 0.2 & 0.3 & 0.1 & 0.3 & 0.1 & & \\
\hline \multirow[t]{2}{*}{ Zoea II } & $\mu \mathrm{g} /$ ind. & 5 & 57.8 & 13.1 & 10.2 & 1.0 & 1.9 & 0.2 & 1.6 & 0.2 & 5.3 & 0.1 \\
\hline & $\% \mathrm{DM}$ & & 12.4 & 2.9 & 2.2 & 0.2 & 0.4 & 0.1 & 0.3 & 0.1 & & \\
\hline \multirow[t]{2}{*}{ Decapodid } & $\mu \mathrm{g} /$ ind. & 1 & 74.9 & & 16.4 & & 3.2 & & 2.7 & & 5.2 & \\
\hline & $\% \mathrm{DM}$ & & 16.3 & & 3.6 & & 0.7 & & 0.6 & & & \\
\hline
\end{tabular}


$\mathrm{DM}$, while the $\mathrm{N}$ and $\mathrm{H}$ values ranged from about $10-12 \%$ and $6-7 \%$, respectively (Table 1). The values for unfed larvae of female $\mathrm{C}$ were slightly below those of fed larvae (Table 1).

\subsection{Exuvial losses}

Very few exuviae were available for elemental analyses, especially in late developmental stages, hence no replicate analyses were possible (Table 4); many exuviae fell rapidly apart shortly after moulting.

The zoeal stages as well as the decapodid stage of $C$. vagans produced strikingly thin and fragile exuviae. Therefore, total exuvial dry mass and $\mathrm{C}, \mathrm{N}, \mathrm{H}$ contents per individual were low, but gradually increased in successive ontogenetic stages, more or less doubling the above values of zoea I exuviation at metamorphosis (Table 3; Fig. 3). The C, N, H values (in percent of exuvial DM) were generally much lower than those of the whole body mass. The $\mathrm{C}: \mathrm{N}$ mass ratio, in contrast, was always higher in the exuviae than in total body DM of larval and juvenile stages (Tables 1 and 4).

In both zoeal stages combined, about $21 \%$ of the initial DM at hatching, $4 \%$ of the initially present $\mathrm{C}$, and about $1 \%$ of both, $\mathrm{N}$ and $\mathrm{H}$ was lost with the shed exuviae. Roughly the same amounts were lost with the decapodid exuvia cast at metamorphosis. The losses in DM, however, were slightly lower in the decapodid, compared to those in the zoeal stages I and II combined (Fig. 3). Total exuvial losses of DM from hatching to metamorphosis (all larval stages combined) amounted to about $172 \mu \mathrm{g}$ DM or $37 \%$ of the initially present dry mass at hatching (Fig. 3).

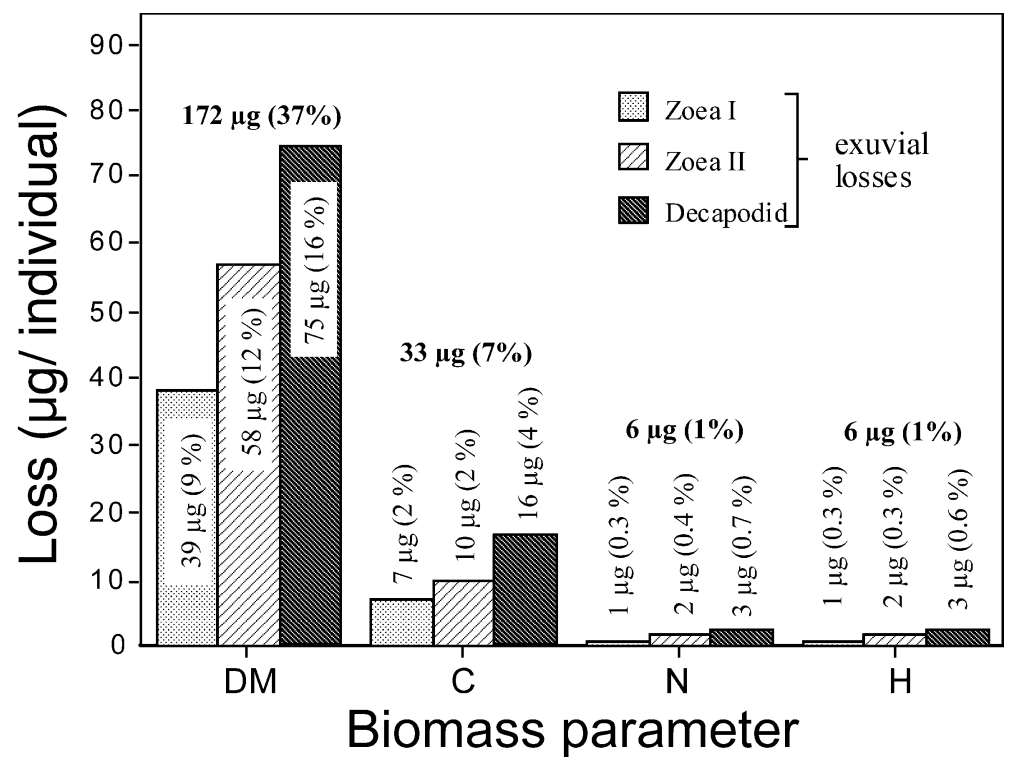

Fig. 3. C. vagans. Exuvial losses of dry mass (DM), carbon (C), nitrogen (N) and hydrogen (H), given in $\mu \mathrm{g} /$ individual $(x \pm$ S.D. $)$ and in percent of the initial biomass at hatching. 
Table 5

Changes in the protein content ( $\mu \mathrm{g} /$ individual) during larval and early juvenile development of $C$. vagans $(-$ Artemia $=$ without Artemia sp.)

\begin{tabular}{|c|c|c|c|c|c|c|c|c|c|}
\hline \multirow[t]{3}{*}{ Female } & & \multicolumn{8}{|c|}{ Developmental stage } \\
\hline & & \multicolumn{3}{|l|}{ Zoea I } & \multicolumn{2}{|l|}{ Zoea II } & \multicolumn{2}{|l|}{ Decapodid } & \multirow{2}{*}{$\frac{\text { Juvenile I }}{\mathrm{d}-49}$} \\
\hline & & $\mathrm{d}-0$ & $d-5$ & $\mathrm{~d}-10$ & $\mathrm{~d}-17$ & $\mathrm{~d}-22$ & $d-34$ & d-39 & \\
\hline \multirow[t]{2}{*}{ A } & $\mu \mathrm{g} / \mathrm{ind}$. & $189.5 \pm 30.7$ & $281.3 \pm 25.2$ & $336.1 \pm 37.8$ & $388.1 \pm 38.6$ & $389.5 \pm 49.1$ & $496.1 \pm 46.8$ & $587.4 \pm 65.6$ & $642.1 \pm 204.8$ \\
\hline & $\% \mathrm{DM}$ & $38.6 \pm 0.7$ & $42.1 \pm 1.6$ & $47.5 \pm 5.8$ & $43.1 \pm 2.5$ & $41.4 \pm 1.9$ & $37.8 \pm 6.5$ & $40.6 \pm 1.4$ & $31.0 \pm 1.7$ \\
\hline \multirow[t]{2}{*}{ B } & $\mu \mathrm{g} / \mathrm{ind}$. & $201.1 \pm 21.1$ & $280.8 \pm 68.6$ & $273.0 \pm 34.3$ & $326.5 \pm 38.5$ & $407.6 \pm 56.9$ & $479.4 \pm 39.4$ & & \\
\hline & $\% \mathrm{DM}$ & $48.0 \pm 6.6$ & $46.5 \pm 6.6$ & $40.9 \pm 1.6$ & $35.9 \pm 2.6$ & $44.2 \pm 5.1$ & $37.4 \pm 1.9$ & & \\
\hline \multirow[t]{2}{*}{$\mathrm{C}-$ Artemia } & $\mu \mathrm{g} /$ ind. & $229.6 \pm 77.6$ & $236.5 \pm 12.0$ & $181.1 \pm 11.9$ & & & & & \\
\hline & $\% \mathrm{DM}$ & $48.3 \pm 1.5$ & $51.9 \pm 2.5$ & $63.9 \pm 2.2$ & & & & & \\
\hline \multirow[t]{2}{*}{$\mathrm{D}$} & $\mu \mathrm{g} / \mathrm{ind}$. & $209.3 \pm 18.6$ & & & & & & & \\
\hline & $\% \mathrm{DM}$ & $49.8 \pm 6.9$ & & & & & & & \\
\hline \multirow[t]{2}{*}{$\mathrm{E}$} & $\mu \mathrm{g} / \mathrm{ind}$. & $191.1 \pm 27.6$ & & & & & & & \\
\hline & $\% \mathrm{DM}$ & $47.2 \pm 3.6$ & & & & & & & \\
\hline
\end{tabular}

d-0: freshly hatched larvae (unfed). 


\subsection{Changes in protein and lipid contents}

The protein content varied from $31 \%$ to $50 \%$ of DM (Table 5). The gradual increase in the absolute protein content (in $\mu \mathrm{g}$ /individual) during larval development showed a similar pattern as observed in elemental composition. Larvae maintained without food lost about $22 \%$ from hatching to day 10 , indicating significant protein utilisation.

Total lipid content increased continuously from hatching to the first juvenile instar (37$95 \mu \mathrm{g}$ /individual, Table 6), however, with variable values in the decapodid stage (Table 6). In terms of $\% \mathrm{DM}$, lipid contents of about $8 \%$ decreased slightly throughout larval development (Table 6). A decreasing lipid content by about $27 \%$ in the decapodid stage a few days before metamorphosis (from day 34 to day 39) indicates a considerable use of lipids (Table 6). Total lipid in larvae kept under starvation conditions decreased from hatching until day 5. This may indicate utilisation of lipids as an energy source during absence of food (Table 6).

\subsection{Fatty acid composition}

The dominant fatty acids during the subsequent larval development of $C$. vagans were $18: 1(n-9), 16: 0$ and $20: 5(n-3)$, contributing on average $20 \%, 15 \%$ and $12 \%$, respectively, to the total fatty acid pool (Table 7). Other important fatty acids were 18:1(n-7), 18:3(n-3), $18: 0$ and $16: 1(n-7)$, contributing $8 \%, 7 \%, 6 \%$ and $4 \%$, respectively, to the total fatty acid pool (Table 7). Other fatty acids occurred only in small amounts and most of these were polyunsaturates. On average, about 15\% saturated, 35\% monounsaturated and 40\% polyunsaturated fatty acids were found throughout larval and early juvenile development (Table 7).

The food offered (Artemia sp. nauplii) was dominated by 18:1(n-9), 18:3(n-3), 16:0 and 16:1(n-7), contributing $29 \%, 22 \%, 12 \%$ and $6 \%$, respectively, to all fatty acids (Table 7 ). The strong variability in fatty acid content as, e.g. observed throughout larval development in 18:3(n-3), might be due to individual feeding conditions of larvae (Table 7). After 10 days of starvation, a dramatic decrease occurred in all previously dominating fatty acids (all $<7 \%$ ).

The contribution of three detected fatty alcohols (14:OA, 16:OA, 18:OA) was extremely low in all samples; they varied from 0 to $3 \%$ of total mass, indicating

Table 6

C. vagans. Total lipid content in fed and unfed $(-$ Artemia $=$ without Artemia) larvae (all in $\mu \mathrm{g} /$ individual and in percent of DM)

\begin{tabular}{|c|c|c|c|c|c|c|c|c|c|c|}
\hline \multirow[t]{3}{*}{ Female } & \multicolumn{10}{|c|}{ Developmental stage } \\
\hline & & \multicolumn{3}{|c|}{ Zoea I } & \multicolumn{2}{|c|}{ Zoea II } & \multicolumn{2}{|c|}{ Decapodid } & \multicolumn{2}{|c|}{ Juvenile I } \\
\hline & & $\mathrm{d}-0$ & $d-5$ & $\mathrm{~d}-10$ & $\mathrm{~d}-17$ & $d-22$ & $\mathrm{~d}-34$ & d-39 & d-49 & $\mathrm{d}-54$ \\
\hline \multirow[t]{2}{*}{ A } & $\mu \mathrm{g} /$ ind. & 37 & 52 & 64 & 60 & 63 & 51 & 37 & 95 & 70 \\
\hline & $\% \mathrm{DM}$ & 8 & 8 & 9 & 7 & 7 & 4 & 3 & 5 & 4 \\
\hline \multirow[t]{2}{*}{$\mathrm{C}-$ Artemia } & $\mu \mathrm{g} /$ ind. & 41 & 11 & 39 & & & & & & \\
\hline & $\% \mathrm{DM}$ & 9 & 2 & 9 & & & & & & \\
\hline
\end{tabular}


Table 7

C. vagans. Changes in fatty acid composition (mass percent of total fatty acids) during larval and early juvenile development, and in the Artemia nauplii offered as food

\begin{tabular}{|c|c|c|c|c|c|c|c|c|c|c|}
\hline \multirow[t]{2}{*}{ Fatty acids } & \multicolumn{3}{|c|}{ Zoea I } & \multicolumn{2}{|c|}{ Zoea II } & \multicolumn{2}{|c|}{ Decapodid } & \multicolumn{2}{|c|}{ Juvenile I } & \multirow[t]{2}{*}{ Artemia sp. } \\
\hline & $\mathrm{d}-0$ & $d-5$ & d-10 & $\mathrm{d}-17$ & $\mathrm{~d}-22$ & d-34 & d-39 & d-49 & d-54 & \\
\hline $13: 0$ & 0.4 & 0.3 & 0.2 & 0.2 & 0,4 & 0.1 & - & - & - & - \\
\hline $14: 0$ & 3.0 & 2.1 & 1.8 & 2.3 & 2.8 & 1.1 & 0.9 & 7.0 & 1.3 & 1.0 \\
\hline $14: 1(n-5)$ & 0.4 & 0.2 & - & - & - & - & - & - & - & 0.1 \\
\hline $15: 0$ & 1.2 & 0.7 & 0.4 & 1.3 & 1.5 & 0.3 & 0.3 & 0.4 & 0.3 & 0.4 \\
\hline $16: 0$ & 18.8 & 13.9 & 13.8 & 16.3 & 15.5 & 13.9 & 11.4 & 17.3 & 11.6 & 11.7 \\
\hline $16: 1(n-7)$ & 3.3 & 3.8 & 3.8 & 3.7 & 3.7 & 4.3 & 4.2 & 9.3 & 3.8 & 6.1 \\
\hline $16: 1(n-5)$ & 0.3 & 0.2 & - & 0.3 & - & 0.1 & 0.1 & 0.2 & 0.1 & 0.2 \\
\hline $16: 2(n-4)$ & 0.7 & 0.4 & 0.5 & 0.4 & 0.3 & 0.2 & 0.2 & 1.9 & - & 0.3 \\
\hline $16: 3(n-4)$ & 0.8 & 0.9 & 0.9 & 1.0 & 1.2 & 1.0 & 0.9 & 1.6 & 0.9 & 1.2 \\
\hline $16: 4(n-1)$ & 0.5 & - & - & 0.2 & - & - & 0.2 & 3.1 & 0.8 & - \\
\hline $17: 0$ & 1.1 & 0.7 & 0.7 & 1.0 & 1.6 & 0.9 & 0.7 & 0.3 & 0.7 & 0.7 \\
\hline $17: 1$ & - & 0.1 & - & 0.3 & - & 0.2 & 0.2 & - & - & 0.6 \\
\hline 18:0 & 7.4 & 7.1 & 5.8 & 6.8 & 7.8 & 6.1 & 5.3 & 2.9 & 5.9 & 3.5 \\
\hline $18: 1(n-9)$ & 12.9 & 19.9 & 20.8 & 20.5 & 21.5 & 25.7 & 24.6 & 12.2 & 24.7 & 29.2 \\
\hline $18: 1(n-7)$ & 7.5 & 8.2 & 8.8 & 7.8 & 8.1 & 12.3 & 10.7 & 2.5 & 10.1 & 7.1 \\
\hline $18: 2(n-6)$ & 2.6 & 9.4 & 4.6 & 6.6 & 5.8 & 5.9 & 4.7 & 0.9 & 4.9 & 5.1 \\
\hline $18: 3(n-6)$ & 0.7 & 0.6 & 1.0 & 0.7 & 0.4 & 2.1 & 0.8 & 0.4 & 1.4 & 1.3 \\
\hline $18: 3(n-3)$ & 0.4 & 0.3 & 10.9 & 11.1 & 5.3 & 0.4 & 15.5 & 0.7 & 14.4 & 21.5 \\
\hline $18: 4(n-3)$ & - & 0.8 & 0.9 & 1.1 & 1.0 & 1.6 & 1.5 & 3.4 & 1.3 & 4.1 \\
\hline $20: 1(n-9)$ & 0.5 & 0.5 & 0.9 & 1.0 & 1.1 & 1.3 & 1.2 & 1.2 & 1.1 & 0.7 \\
\hline $20: 1(n-7)$ & 0.7 & 0.5 & 0.3 & 0.2 & - & 0.3 & 0.3 & 0.2 & - & - \\
\hline $20: 2(n-6)$ & 0.4 & 2.3 & - & 0.1 & 0.6 & 0.5 & 0.4 & - & - & - \\
\hline $20: 3(n-6)$ & 0.5 & 0.3 & - & 0.2 & 0.3 & 0.1 & 0.2 & 0.2 & - & 0.2 \\
\hline $20: 3(n-3)$ & - & 0.3 & 0.4 & 0.4 & 3.5 & 1.0 & 0.8 & 1.1 & 0.9 & 0.2 \\
\hline $20: 4(n-6)$ & 3.6 & 3.0 & 2.9 & 2.0 & 1.6 & 3.1 & 2.8 & 0.7 & 2.7 & 1.0 \\
\hline $20: 4(n-3)$ & - & 0.3 & - & 0.3 & - & 0.5 & 0.4 & - & - & 0.3 \\
\hline $20: 5(n-3)$ & 16.3 & 12.7 & 11.7 & 8.6 & 8.7 & 11.3 & 8.1 & 19.7 & 9.9 & 3.5 \\
\hline $22: 1(n-11)$ & - & - & - & - & - & - & - & 1.8 & - & - \\
\hline $22: 1(n-9)$ & 0.4 & 0.2 & - & 0.4 & - & 0.2 & 0.1 & 0.2 & - & - \\
\hline $22: 4(n-3)$ & 2.5 & 1.3 & 1.1 & 1.0 & 1.2 & 0.6 & 0.5 & 0.8 & 0.7 & - \\
\hline $22: 5(n-3)$ & 1.1 & 0.6 & 0.4 & 0.8 & 0.3 & 0.2 & - & 1.3 & - & - \\
\hline $22: 6(n-3)$ & 12.1 & 8.4 & 7.3 & 3.6 & 5.8 & 4.4 & 2.8 & 8.5 & 3.5 & - \\
\hline 24:1(n-11) & - & - & - & - & - & - & - & 0.4 & - & - \\
\hline$\Sigma$ Saturates & 31.8 & 24.7 & 22.8 & 27.7 & 29.6 & 22.4 & 18.7 & 28.0 & 19.7 & 17.3 \\
\hline$\Sigma$ Monounsats. & 26.0 & 33.7 & 34.6 & 34.2 & 34.4 & 44.4 & 41.4 & 27.9 & 39.8 & 44.1 \\
\hline$\Sigma$ Polyunsats. & 42.2 & 41.6 & 42.6 & 38.1 & 36.0 & 33.2 & 39.9 & 44.1 & 40.5 & 38.6 \\
\hline
\end{tabular}

that wax esters were negligible as an energy source during starvation and metamorphosis.

\section{Discussion}

Based on the comprehensive work of Thorson (1936, 1950), it has been suggested that polar marine invertebrates tend to reduce planktotrophic larval developments 
(Mileikovsky, 1971). This generalisation generated intense scientific discussions and was frequently modified (e.g. Chia, 1974; Stanwell-Smith et al., 1999; Gallardo and Penchaszadeh, 2001; see also Arntz and Gili, 2001). At high latitudes, there exists a conspicuous mismatch of long larval development due to low temperatures and short intensed periods of primary production, i.e. food availability (Clarke, 1982, 1987). This should select against a planktotrophic mode of development, in particular in the high Antarctic regime. Studies on invertebrate reproduction in the Southern Ocean demonstrated that reproductive traits in cold environments are more diverse than previously assumed. This includes a high frequency of brooding species including those with benthic, demersal or direct larval development (Bosch and Pearse, 1990), which is often associated with various levels of food independence. Pelagic studies showed that the meroplanktonic community may be more diverse than previously recorded, occurring in low abundance, but with long-lived and slowly developing larvae (Stanwell-Smith et al., 1999). Such modes, however, require some degree of endotrophic or partially lecithotrophic development allowing for a high resistance to starvation. These processes are still far from understood in high latitudinal benthic decapods.

In the subantarctic Magellan region, the meroplanktonic community is dominated by decapod larvae (Lovrich, 1999; Thatje et al., 2003b). For instance, endotrophic foodindependent, demersal modes of development have been observed in some lithodid crabs (e.g. Calcagno et al., 2003; Lovrich et al., 2003), but planktotrophic or partially food-independent developments seem to be the dominating modes in decapod reproduction (Thatje et al., 2003b). The use of plankton as a food source basically requires a strong synchronisation of larval release with seasonal peaks of plankton productivity. Such hatching processes may be triggered by sinking phytoplankton particles to the sea floor, or directly by the development of a phytoplankton bloom (Starr et al., 1990, 1994). On the other hand, some decapods at high latitudes show extended hatching periods of varying length, ranging from a few weeks to months (e.g. Lithodidae: Paralomis granulosa, Lithodes santolla, Thatje et al., 2003a; Crangonidae: Notocrangon antarcticus, Bruns, 1992). This same pattern is evident also in C. vagans with 2 3 weeks of duration (Thatje et al., 2004). Extended periods of larval release in combination with high larval resistance to starvation (for C. vagans, see Thatje et al., 2004) reduce the necessity of synchronisation with food availability (Stanwell-Smith et al., 1999). In addition, low daily hatching rates should help to avoid predation on the small offspring (Thatje et al., 2003a). Extended hatching periods occur also in decapod species with completely food-independent larvae (e.g. the lithodid P. granulosa; Calcagno et al., 2003). The abbreviated larval development in $C$. vagans may be another important adaptation to food limitation, as it allows a better synchronisation with food availability. Lack of variability in the number of instars appears to be typical of high latitudinal caridean species, again aiding to synchronisation with peaks in plankton production (high variability in larval developmental pathways is typical of low latitude decapods, i.e. tropic carideans, Wehrtmann and Albornoz, 1998; Anger, 2001). The production of extremely thin exuviae in $C$. vagans is an energy saving mechanism (Anger, 2001). This was demonstrated also in lithodid crab larvae from cold-temperate regions (e.g. Lovrich et al., 2003). 
Most campylonotid species (C. vagans, C. semistriatus, C. rathbunae) apparently have an abbreviated larval development (Thatje et al., 2001). Larvae of these species usually occur in extremely low abundance in the plankton, which is typical of high latitudinal meroplankton communities (Stanwell Smith et al., 1999; Thatje et al., 2003b). Since also larvae of the deepwater species C. capensis migrate vertically to the upper ocean stratum (larvae have been found from $100 \mathrm{~m}$ depth to sea surface, Thatje et al., 2001), a planktotrophic and abbreviated larval development may be typical of this family. Although larvae of $C$. vagans showed a carnivorous feeding behaviour, they may actually be omnivorous. Nutritional dependence on secondary production (mesozooplankton) would explain an extended mode of hatching, since the development of a phytoplankton bloom would only predict subsequent food availability in developing zooplankton. However, Bruns (1992) assumed that the extended hatching mode in a high Antarctic herbivorous caridean, $N$. antarcticus, may represent a mechanism of synchronisation with primary production which, in the case of the high Antarctic shelf, is highly variable due to annual variability in the sea ice extent (Strass and Fahrbach, 1998). Recently, Graeve and Wehrtmann (2003) demonstrated that eggs of polar crustaceans do not contain significantly more lipids than species from tropical regions (see also Wehrtmann and Kattner, 1998). This was surprising, because previous studies suggested that high latitudinal crustacean eggs, which are generally larger, have a higher nutrient content per embryo (Clarke, 1993), as the adult Antarctic shrimps appear to accumulate large amounts of lipids (Clarke, 1983, 1987). Larger eggs are assumed to reflect environmental conditions such as low temperature, often associated with hatching of advanced larvae and an abbreviated development (for discussion, see Clarke, 1993; Wehrtmann and Kattner, 1998; Anger et al., 2002). Total lipid contents of C. vagans larvae are low, but in the usual range of carideans from temperate zones (Graeve and Wehrtmann, 2003). Starved larvae rely mainly on proteins as internal energetic contents. The dominating fatty acids utilised during the course of larval development are very similar to the fatty acids found in eggs of Antarctic shrimps (Graeve and Wehrtmann, 2003). The variability in the fatty acid composition during the larval development in C. vagans is high (Table 7). This may be due to intraspecific variability in larval fitness and feeding condition. Especially the fatty acid 18:3(n-3) which resulted mainly from food uptake (Table 7) may indicate feeding conditions of larvae. Other dominant fatty acids remained comparably constant during the complete larval development (Table 7). Larval starvation is especially known before ecdysis (Anger, 2001) and the fatty acid composition should help to distinguish periods of active feeding from starvation. However, since our samples were always taken at days 5 and 10 of each stage, but subsequent larval stages are of different length in duration (Thatje et al., 2004, zoea I: 12 , zoea II: 17, decapodid: 15 days in duration), we need a higher temporal dissolution in future sampling.

In conclusion, the present observations of planktotrophic development in a caridean shrimp from the cold-temperate Magellan region suggests that actively feeding decapod larvae with a high starvation resistance, in combination with a strongly abbreviated mode of larval development, is a successful reproductive strategy at higher latitudes. 


\section{Acknowledgements}

This project was funded by the International Bureau of the German Ministry of Research (BMBF, project no. ARG 99/002), the Argentine Secretaría Nacional para la Tecnología, Ciencia e Inovación Productiva (SETCIP), and the Alfred Wegener Institute for Polar and Marine Research, Bremerhaven, Germany. Marcelo Gutiérrez was a great help at sea and in the lab. We would like to thank Petra Wencke for her assistance in the fatty acid analyses. [SS]

\section{References}

Anger, K., 2001. The biology of decapod crustacean larvae. Crustacean Issue 14. A.A. Balkema Publishers, Swets and Zeitlinger, Lisse, ISSN 0168-6456, 1-420 pp.

Anger, K., Harms, J., 1990. Elemental (CHN) and proximate biochemical composition of decapod crustacean larvae. Comp. Biochem. Physiol. 97B, 69-80.

Anger, K., Moreira, G.S., Ismael, D., 2002. Comparative size, biomass, chemical composition (C, N, H) and energy concentration of caridean shrimp eggs. Invertebr. Reprod. Dev. 42, 83-93.

Arana, P.M., Retamal, M.A., 1999. Nueva distribución de Paralomis birsteini Macpherson 1988 en aguas antárticas (Anomura, Lithodidae, Lithodinae). Invest. Mar. (Valparaíso) 27, 101-110.

Arntz, W., Gili, J.S., 2001. A case for tolerance in marine ecology: let us not put out the baby with the bathwater. Sci. Mar. 65, 283-299.

Arntz, W.E., Brey, T., Gerdes, D., Gorny, M., Gutt, J., Hain, S., Klages, M., 1992. Patterns of life history and population dynamics of benthic invertebrates under the high Antarctic conditions of the Weddell Sea. In: Colombo, G., Ferrari, I., Ceccherelli, V.U., Rossi, R. (Eds.), Marine Eutrophication and Population Dynamics: Proc. 25th European Marine Biology Symposium. Olsen and Olsen, Fredensborg, Denmark, pp. 221-230.

Bosch, I., Pearse, J.S., 1990. Developmental types of shallow-water asteroids of McMurdo Sound, Antarctica. Mar. Biol. 104, 41-46.

Bruns, T., 1992. Experimentelle Untersuchungen zur Larvalentwicklung antarktischer Garnelen (Decapoda, Natantia). Diplomarbeit, University of Osnabrück, 1-129 pp. (Master's thesis).

Calcagno, J.A., Thatje, S., Anger, K., Lovrich, G.A., Kaffenberger, A., 2003. Changes in biomass and chemical composition during lecithotrophic larval development of the Southern stone crab, Paralomis granulosa (Jacquinot). Mar. Ecol. Prog. Ser. 257, 189-196.

Chia, F.S., 1974. Classification and adaptive significance of developmental patterns in marine invertebrates. Thalass. Jugosl. 10, 267-284.

Clarke, A., 1982. Temperature and embryonic development in polar marine invertebrates. Int. J. Invertebr. Reprod. 5, 71-82.

Clarke, A., 1983. Life in cold water: the physiological ecology of polar marine ectotherms. Oceanogr. Mar. Biol. Ann. Rev. 21, 341-453.

Clarke, A., 1987. Temperature, latitude and reproductive output. Mar. Ecol. Prog. Ser. 38, 89-99.

Clarke, A., 1993. Egg size and egg composition in polar shrimps (Caridea; Decapoda). J. Exp. Mar. Biol. Ecol. $168,189-203$

Crame, J.A., 1999. An evolutionary perspective on marine faunal connections between southernmost South America and Antarctica. Sci. Mar. 63 (Suppl. 1), 1-14.

Crame, J.A., 2000a. Taxonomic diversity gradients through geological time. Divers. Distrib. 7, 175-789.

Crame, J.A., 2000b. The nature and origin of taxonomic diversity gradients in marine bivalves. In: Harper, H.M., Taylor, J.D., Crame, J.A. (Eds.), The Evolutionary Origin of the Bivalva. Spec. Publ., vol. 177. Geological Society, London, pp. 347-360.

Gallardo, C.S., Penchaszadeh, P.E., 2001. Hatching mode and latitude in marine gastropods: revisiting Thorson's paradigm in the southern hemisphere. Mar. Biol. 138, 547-552.

Gorny, M., 1999. On the biogeography and ecology of the Southern Ocean decapod fauna. Sci. Mar. 63 (Suppl. 1), $367-382$. 
Graeve, M., Wehrtmann, I.S., 2003. Lipid and fatty acid composition of Antarctic shrimp eggs (Decapoda: Caridea). Polar Biol. 26, 55-61.

Kattner, G., Fricke, H.S.G., 1986. Simple gas-liquid chromatographic method for the simultaneous determination of fatty acids and alcohols in wax esters of marine organisms. J. Chromatogr. 361, 263-268.

Kattner, G., Hagen, W., Graeve, M., Albers, C., 1998. Exceptional lipids and fatty acids in the pteropod Clione limacina (Gastropoda) from both polar oceans. Mar. Chem. 61, 219-228.

Klages, M., Gutt, J., Starmans, A., Bruns, T., 1995. Stone crabs close to the Antarctic continent: Lithodes murrayi Henderson, 1888 (Crustacea; Decapoda; Anomura) off Peter I Island $\left(68^{\circ} 51^{\prime} \mathrm{S}, 90^{\circ} 51^{\prime} \mathrm{W}\right)$. Polar Biol. 15, 73-75.

Knox, G.A., 1994. The Biology of the Southern Ocean. Cambridge University Press, Cambridge, UK, pp. $1-444$.

Lovrich, G.A., 1999. Seasonality of larvae of Brachyura and Anomura (Crustacea, Decapoda) in the Beagle Channel. Argent. Sci. Mar. 63 (Suppl. 1), 347-354.

Lovrich, G.A., Thatje, S., Calcagno, J.A., Anger, K., Kaffenberger, A., 2003. Changes in biomass and chemical composition during lecithotrophic larval development of the Southern king crab Lithodes santolla (Molina). J. Exp. Mar. Biol. Ecol. 288, 65-79.

Lowry, D., Rosenberg, N., Farr, A., Randall, R., 1951. Protein measurement with the Folin phenol reagent. J. Biochem. Chem. 193, 265-275.

Mileikovsky, S.A., 1971. Types of larval development in marine bottom invertebrates, their distribution and ecological significance: a re-evaluation. Mar. Biol. 10, 193-213.

Paschke, K., 1998. Untersuchungen zum Energiestoffwechsel während der Embryonalentwicklung der NordseeGarnele Crangon crangon (Linnaeus 1758) (Decapoda: Caridea). PhD thesis (unpublished), University of Hamburg, Hamburg.

Pearse, J.S., McClintock, J.B., Bosch, I., 1991. Reproduction of Antarctic marine invertebrates: tempos, modes and timing. Am. Zool. 31, 65-80.

Pfaff, K., 1997. Einfluß der Salinität auf den Stoffbestand der Larvenstadien einer marinen Dekapodenart. Master's thesis, University of Darmstadt (unpublished).

Sokal, R.R., Rohlf, F.J., 1995. Biometry, The Principles and Practice of Statistics in Biological Research. Freeman, New York, pp. 1-887.

Stanwell-Smith, D., Peck, L.S., Clarke, A., Murray, A.W.A., Todd, C.D., 1999. The distribution, abundance and seasonality of pelagic marine invertebrate larvae in the maritime Antarctic. Phil. Trans. R. Soc. Lond. B 354, $471-484$.

Starr, M., Himmelman, J.H., Therriault, J.-C., 1990. Direct coupling of marine invertebrate spawning with phytoplankton blooms. Science 247, 1071-1074.

Starr, M., Therriault, J.-C., Conan, G.Y., Comeau, M., Robichaud, G., 1994. Larval release in a sub-euphotic zone invertebrate triggered by sinking phytoplankton particles. J. Plankton Res. 16, 1137-1147.

Strass, V.H., Fahrbach, E., 1998. Temporal and regional variation of sea ice draft and coverage in the Weddell Sea obtained from upward looking sonars. In: Jeffries, M.O. (Ed.), Antarctic Sea Ice: Physical Processes, Interactions and Variability. Antarct. Res. Ser., vol. 74. AGU, Washington, DC, pp. 123-139.

Thatje, S., 2003. Campylonotus arntzianus, a new species of the Campylonotidae (Crustacea: Decapoda: Caridea) from the Scotia Sea (Antarctica). Polar Biol. 26, 242-248.

Thatje, S., Lovrich, G.A., 2003. Decapodid and early juvenile development in the protandrous shrimp Campylonotus vagans Bate, 1888 (Crustacea: Decapoda: Caridea), with notes on larval morphology. J. Mar. Biol. Assoc. U.K. 83 (1), 103-109.

Thatje, S., Bacardit, R., Romero, M.C., Tapella, F., Lovrich, G.A., 2001. Description and key to the zoeal stages of the Campylonotidae (Decapoda, Caridea) from the Magellan Region. J. Crustac. Biol. 21, $492-505$.

Thatje, S., Calcagno, J.A., Lovrich, G.A., Sartoris, F.J., Anger, K., 2003a. Extended hatching rhythms in the subantarctic lithodid crabs Lithodes santolla and Paralomis granulosa (Crustacea: Decapoda). Helgol. Mar. Res. 57, 110-113.

Thatje, S., Schnack-Schiel, S., Arntz, W.E., 2003b. Developmental trade-offs in Subantarctic meroplankton communities and the enigma of low decapod diversity in high southern latitudes. Mar. Ecol. Prog. Ser. 260, 195-207. 
Thatje, S., Lovrich, G.A., Anger, K., 2004. Abbreviated larval development in a subantarctic caridean shrimp, Campylonotus vagans Bate, 1888. J. Exp. Mar. Biol. Ecol. (in press).

Thorson, G., 1936. The larval development, growth and metabolism of Arctic marine bottom invertebrates compared with those of other seas. Medd. Om. Grönland 100, 1-155.

Thorson, G., 1950. Reproductive and larval ecology of marine bottom invertebrates. Biol. Rev. 25, $1-45$.

Torti, M.R., Boschi, E.E., 1973. Nuevos aportes al conocimiento de los crustáceos decápodos Caridea del genero Campylonotus Bate, 1888. Physis, Secc. A, Buenos Aires 32, 65-84.

Wehrtmann, I.S., Albornoz, L., 1998. Larval development of Nauticaris magellanica (A. Milne Edwards, 1891) (Decapoda: Caridea: Hippolytidae), reared under laboratory conditions. Bull. Mar. Sci. 62, 45-72.

Wehrtmann, I.S., Kattner, G., 1998. Changes in volume, biomass, and fatty acids of developing eggs in Nauticaris magellanica (Decapoda: Caridea): a latitudinal comparison. J. Crustac. Biol. 18, 413-422. 